\title{
Foreign Aid and Revenue: Still a Crowding Out Effect?
}

Dora Benedek, Ernesto Crivelli, Sanjeev Gupta, and Priscilla Muthoora 


\title{
IMF Working Paper
}

Fiscal Affairs Department

\section{Foreign Aid and Revenue: Still a Crowding Out Effect?}

\section{Prepared by Dora Benedek, Ernesto Crivelli, Sanjeev Gupta, and Priscilla Muthoora ${ }^{1}$}

Authorized for distribution by Sanjeev Gupta

July 2012

\section{This Working Paper should not be reported as representing the views of the IMF.} The views expressed in this Working Paper are those of the author(s) and do not necessarily represent those of the IMF or IMF policy. Working Papers describe research in progress by the author(s) and are published to elicit comments and to further debate.

\begin{abstract}
This paper reexamines the relationship between aid and domestic tax revenues using a more recent and comprehensive dataset covering 118 countries for the period 1980-2009. Overall, our results support earlier findings of a negative association between net Official Development Assistance (ODA) and domestic tax revenues, but this relationship appears to have weakened in reflection of greater efforts at mobilizing domestic revenues in many countries. The composition of net ODA matters: ODA grants are associated with lower revenues, while ODA loans are not. The paper further finds that net ODA and grants are negatively associated with VAT, excise and income tax revenues, but have a positive relationship with trade taxes. Aid has a particularly strong negative effect on domestic tax revenues in low-income countries and incountries with relatively weak institutions.
\end{abstract}

JEL Classification Numbers: F35, H2, H27

Keywords: Foreign Aid, Taxation

Author's E-Mail Address: dbenedek@imf.org, ecrivelli@imf.org, sgupta@imf.org, pmuthoora@imf.org

\footnotetext{
${ }^{1}$ We are grateful for comments received from Alan Carter, Paddy Carter, Ruud de Mooij, Francesco Grigoli, Michael Keen, Paolo Mauro, Oliver Morrissey, Jean-Claude Nachega, Marcos Poplawski, Agustin Roitman, Gregoire Rota-Graziosi, Eduardo Ruggiero, and Philippe Wingender. Helpful comments were also received from participants at seminars at the IMF and World Bank, the Fourth International Tax Dialogue Conference in New Delhi and the Development Studies Association/European Association of Development Institutions 2011 Conference in York, UK. We would like to thank Alvar Kangur for his advice on econometric issues and Petra Dacheva, Oana Luca, and Kelsey Moser for help with consolidating the data. The usual caveats apply.
} 
Abstract...... 1

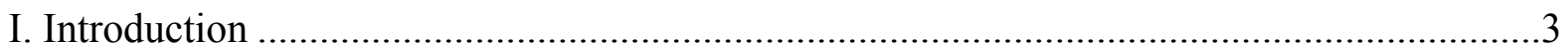

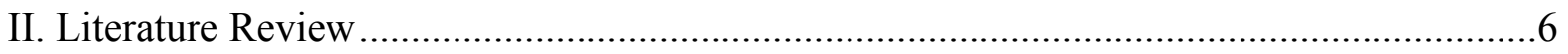

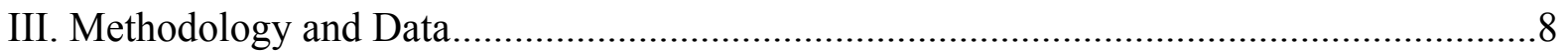

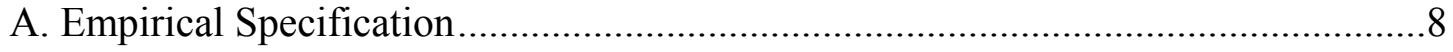

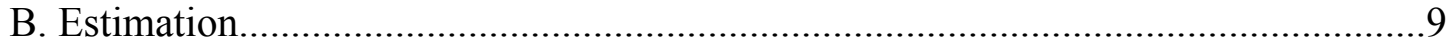

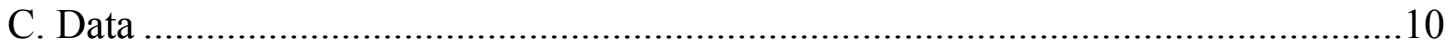

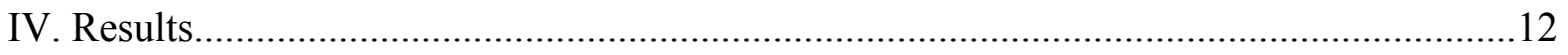

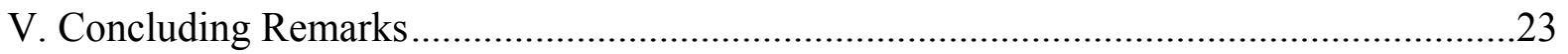

Tables

1. Net ODA Grants and Loans and Total Tax Revenues ................................................13

2. Effect of Net ODA Grants and Loans on Each Type of Tax Revenue ................................16

3. Effect of ODA on Total Tax Revenue by Countries' Income Level ..................................19

4. Effect of ODA on Total Tax Revenue by Region.........................................................21

5. Impact of ODA on Total Tax Revenue in Countries with Weak Institutions......................22

Figures

1. Average Net ODA and Tax Revenue in Low- and Middle-Income Countries.....................3

2. Average Taxes and Total Net ODA, 1980-2009 .........................................................11

3. Structural Benchmarks and Indicative Targets in IMF-Supported Programs.....................15

Appendixes

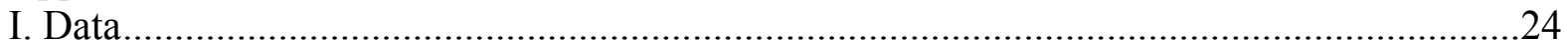

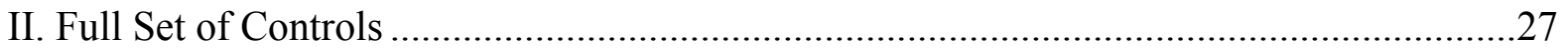

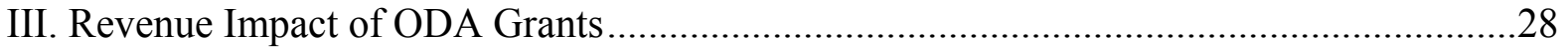

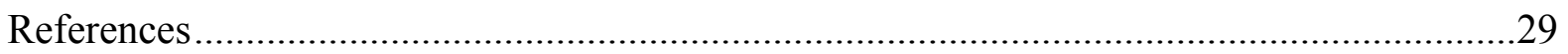




\section{INTRODUCTION}

Net Official Development Assistance (ODA) to developing countries has averaged between 3.7 and 6.7 percent of GDP during 1980-2009, amounting to around 20-40 percent of average tax revenues. The relatively high share of aid in government budgets in some countries has raised concerns about the detrimental effects of aid dependency on domestic revenue effort, spending programs and budget planning as well as institution-building (Gupta and Tareq, 2008). This has prompted some scholars (Djankov, Montalvo, and Reynal-Querol, 2008) to argue that windfalls from foreign aid can generate a bigger resource curse than natural resources in terms of their impact on democracy and rent-seeking behavior. A more nuanced view is that aid is different from natural resources (notably oil) as it is delivered through technical assistance and projects, packaged with conditions, and debt relief. As such, each modality for delivering aid is likely to influence incentives of governments differently (Collier, 2006; Collier and Venables, 2008).

A data plot suggests a negative association between total net ODA and total tax revenues (Figure 1). Between 1980 and 1995, when foreign aid as a share of GDP was increasing, average tax revenue in relation to GDP decreased slightly. Post-1995, a decline in the share of total net ODA to GDP was accompanied by higher tax revenues as percentage of GDP.

Figure 1. Average Net ODA and Tax Revenue in Low- and Middle-Income Countries, 1980-2009

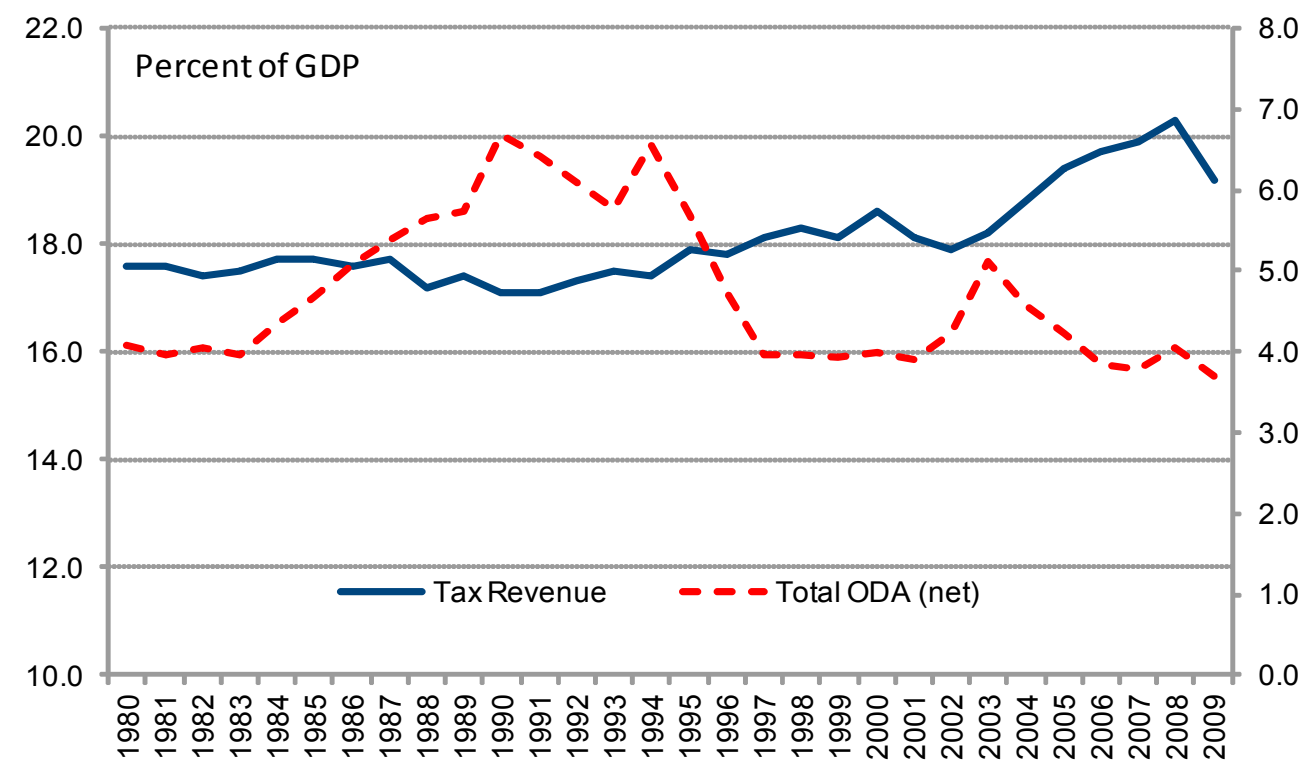

Source: IMF and OECD.

Note: Tax revenue is measured on the left axis, while total ODA is measured on the right axis. 
The relationship between aggregate tax and aid variables ${ }^{2}$ may, however, mask important differences in the aid-taxation relationship, depending on the composition of aid or type of tax. In an earlier paper, Gupta et al. (2004) examined the revenue response to foreign aid and found that total net ODA has a negative association with government revenues. They also concluded that the effect depends on the composition of aid: while grants have a negative effect on revenues, loans have no significant or positive effect. They argued that their results may reflect the fact that loans have to be repaid eventually, while grants represent real transfers from abroad. Moreover, they found that although the effect of grants is modest on average, it is higher in countries with weak institutions. In these countries, the decline in domestic revenues is almost as much as the increase in grants.

The above results were, however, recently criticized on several grounds. A few studies found them to be sensitive to changes in the composition and length of the estimation sample. The critics further argued that the methodology overlooked the differential effect of aid on the tax system, most notably that import taxes might increase with aid while that other taxes (perhaps as a result of this) may stay flat or decline. They also noted that non-random allocation of aid (for example, systematic aid disbursements to countries with good policies or good institutions) is likely to bias the results. (For example, see Moss, Pettersson, and van de Walle, 2008; Carter, 2011; and Clist and Morrissey, 2011).

The purpose of the present paper is to revisit this issue by using a more recent and comprehensive dataset covering 118 countries during 1980-2009. In doing so, we address the above critiques in the recent studies. Specifically, we examine the sensitivity of the results to sample composition using recent data on aid and taxation and we disaggregate revenue data to examine the potentially differential effects of aid on various types of taxes. We also address concerns related to the endogeneity of aid in our estimations.

Overall, our results corroborate those of the Gupta et al. (2004) paper. An increase in net ODA is associated with lower tax revenue, but the size of the association is smaller than found earlier, reflecting efforts being made by countries to strengthen their revenue systems. The composition of net ODA matters. ODA provided in the form of grants is associated with lower total revenue, while loans are not. Results by type of taxes confirm the differential effects of aid on taxation. We find that net ODA (and ODA grants) is negatively related to VAT, excise and income tax revenues and positively associated with trade taxes, as increased aid facilitates higher imports.

\footnotetext{
${ }^{2}$ The terms foreign aid and net ODA are used interchangeably in the paper.
} 
We perform several robustness checks. First, we divide countries into three groups based on their income level. Second, we use five regional categories. The main findings are that aid has a negative association with tax revenues principally in low-income countries. In terms of regional composition, we obtain results for Africa, Asia-Pacific, and Europe which are similar to those found for the total sample. Finally, we control for the quality of institutions and find a strong negative impact of aid on revenues in highly corrupt countries.

The results from this study should contribute to the ongoing policy debate on the role of aid and revenue mobilization in meeting developmental goals. In particular, the G20 countries at the Seoul Summit in November 2010 emphasized the need for further provision of ODA to low-income countries, while recognizing the importance of domestic resource mobilization for inclusive, sustainable, and resilient growth in recipient countries. ${ }^{3}$ Investment in social and physical infrastructure requires substantial and sustained financial resources that can only be provided by additional domestic revenues. The UNDP has estimated that the minimum level of tax revenues needed to reach the Millennium Development Goals (MDG) is 20 percent of $\mathrm{GDP}^{4}$ and studies suggest that there is scope for raising additional revenue in many developing countries by broadening tax bases, improving compliance and strengthening administrative systems (IMF, 2011). A UN report, using a sample of five developing countries, estimates that additional domestic revenue of 4 percent of GDP is needed to fund the achievement of the MDGs. ${ }^{5}$ The focus on domestic resource mobilization in developing countries has assumed further importance in light of the rising debt-to-GDP ratio of traditional donors in the aftermath of the 2008 financial crisis.

The paper is organized as follows. In Section II, we review the relevant literature. Section III presents the empirical specification and estimation strategy, and describes the dataset used for our analyses. The main results are provided in Section IV and the paper concludes in Section V.

\footnotetext{
${ }^{3}$ The G20 Seoul Summit Leaders’ Declaration, November 11-12, 2010.

4 "What Will It Take To Achieve the Millennium Development Goals? An International Assessment," UNDP, June 2010, http://content.undp.org/go/cms-service/stream/asset/\%3Fasset id\%3D2620072\&sa=U\&ei=9d6ToLnBtL82gWDm73LBw\&ved=0CA8QFjAA\&usg=AFQjCNFdbQQPuhLOfiww 1KDSUbOJB5GPw

5 “Investing in Development, A Practical Plan to Achieve the Millennium Development Goals," UN Millennium Report, 2005, http://www.unmillenniumproject.org/reports/fullreport.htm .
} 


\section{Literature REVIEW}

Studies of the relationship between aid and taxation are motivated by the theoretical framework of the fiscal response model developed by Heller (1975) and its subsequent extensions. The model features, in its most basic form, a benevolent government minimizing a loss function subject to targets (on economic growth or welfare, for example) and a budget constraint which includes aid. This yields testable predictions, under specific assumptions, about the behavior of budgetary aggregates in response to aid. Given exogenous government expenditure and borrowing, for example, this model can be used to show how using aid as a substitute for domestic revenue would be a rational choice, particularly if domestic revenue is distortionary. In the more general case where government decisions and aid are endogenous, the interaction between donors and recipient countries can affect the nature of the equilibrium. For instance, a Samaritan dilemma may occur where the recipient country maintains its poor tax performance strategically in order to continue to receive higher concessional aid (see for example Gibson et al, 2005). Thus, the relationship between aid and taxation is not straightforward, but rather an empirical question.

Political economy considerations provide additional support to the argument that aid may discourage taxation by recipient governments. A key argument of the aid dependency literature, for example, is that aid lowers tax revenue because it undermines the development of domestic institutions that support tax administration and good governance (Knack, 2000; Heller and Gupta, 2002; Brautigam and Knack, 2004; and Moss et al., 2008).

Evidence of a negative relationship between aid and tax revenue has been borne out in the data in several studies. Ghura (1998), using data for a sample of 39 sub-Saharan African countries for the period 1985-96, finds that aid has a statistically significant negative effect on the ratio of taxes to GDP. Remmer (2004) uses a broader sample of 120 developing countries over the period 1970-99. She finds a negative relationship between three different measures of aid (aid to GNI, aid to imports, and aid to government expenditure) and changes in tax revenue to GDP. As noted above, Gupta et al. (2004) find similar results. Moreover, they show that the negative effect of ODA grants is stronger in countries with weak institutions. Knack (2009) also finds a robust negative relationship between sovereign rents (from aid and natural resources) and taxation.

A number of recent contributions have however argued that the results are sensitive to the composition and scope of the estimation sample. Clist and Morrissey (2011), extending the time period of the Gupta et al. (2004) database, and re-estimating the relationship between aid and taxation from the mid-1980s to 2005 find a positive association between aid and taxation. They argue that this reflects a break in pattern of allocation of aid since the mid1980s, when aid became conditional on implementation of good policies or concomitant structural reforms. This argument is central to Carter's (2011) critique of existing studies on aid and taxation. He argues that the econometric evidence to date is inconclusive because of 
failures to adequately address the endogenous nature of aid. That is, countries are rewarded with higher aid when they follow sound policies. In addition, he suggests that existing studies are characterized by model misspecification, arising from the omission of certain variables or the assumption of long-run homogeneity of aid across countries. Beyond econometrics, Carter argues that there are two important conceptual limitations in previous research on aid and taxation. The first is the failure to model aid and government response in a dynamic forward-looking context, i.e. model the effect of future aid on current spending or tax policy decisions. The second is the failure to allow for a differential impact of aid on the various taxes that make up the tax structure.

Carter's critique of the literature is, in our view, an important contribution and has implications on ongoing and future research on the aid-taxation relationship. In addition to emphasizing the usefulness of single country time series studies of the effects of aid and tax revenue, ${ }^{6}$ it suggests that the following extensions to panel data studies could usefully contribute to the literature and policy debate:

- $\quad$ Running additional robustness checks with extended datasets to examine the sensitivity of the aid-taxation relationship.

- Improving model specification by controlling for the endogeneity of aid, differences in countries' tax structures, etc.

- Disaggregating tax revenue to examine whether aid has differential impact on various components of taxes.

- Modeling aid and taxation as a dynamic and forward-looking process.

Data limitations do not allow us to address the fourth issue adequately as the use of dynamic heterogeneous panel data techniques (our preferred method) requires a sufficiently long time series with no missing observations. Therefore, the paper focuses on points 1 through 3 among other issues.

\footnotetext{
${ }^{6}$ See, for example, Fagernas and Roberts (2004a and 2004b); Fagernas and Schurich (2004c) and Osei et al. (2005) for studies on Uganda, Zambia, Malawi, and Ghana. These studies highlight the heterogeneity of experiences of countries, in terms of supporting tax policy and tax administration reforms, which can affect the aid-taxation relationship. Earlier single country studies yielded mixed results. For example, Pack and Pack (1990) found a positive relationship between aid and revenue in Indonesia, while Franco-Rodriguez et al. (1998) found a negative relationship for Pakistan.
} 


\section{Methodology ANd DATA}

\section{A. Empirical Specification}

To test how aid may affect tax revenue, the estimating equation (1) considers tax revenue in relation to GDP (in aggregate and by components) as a function of aid (ODA), allowing for disaggregation between grants $\left(O D A_{-}\right.$GRANTS) and loans (ODA_LOANS), and potential non-linear effects, captured by the squared term. We also include a large set of control variables in $X$ :

$[T A X / G D P]_{i t}=\beta_{0}+\beta_{2} . O D A_{-} G R A N T S_{i t}+\beta_{3} . O D A_{-} L O A N S_{i t}+\beta_{4} \cdot\left(O D A_{-} G R A N T S\right)^{2}+$ $\beta_{5} \cdot\left(O D A_{-} L O A N S\right)^{2}+\beta_{6} X_{i t}+\alpha_{i}+\mu_{t}+\varepsilon_{i t}$

Where TAX/GDP is in logs (in aggregate or by component taxes); ODA_GRANTS and ODA_LOANS are also expressed relative to GDP. The coefficient attached to ODA variable measures the semi-elasticity of the tax revenue ratio in response to a one percentage point change in the ODA ratio. Also $i=1, \ldots, N$ and $t=1, \ldots, L$ are respectively country and time indicators (so that $\alpha_{\mathrm{i}}$ and $\mu_{\mathrm{t}}$ are country- and time-specific effects).

The control variables are drawn from previous studies that analyzed the determinants of the tax ratio (Ghura, 1998) and tax effort (see Sen Gupta, 2007, for example). In particular, the overall development of the economy, measured by GDP per capita, is expected to show a positive correlation with revenue because of a higher degree of economic and institutional sophistication. A higher share of agriculture in value-added is expected to be negatively associated with revenue because agriculture is harder to tax, particularly if carried out informally or on a subsistence basis. By contrast, a higher industry value added in GDP is associated with higher revenues. The degree of trade openness, measured as the sum of the shares of imports and exports in GDP, can present either sign. Rodrik (1998) argues that more open countries are vulnerable to risks and, given the need for social insurance, therefore tend to have bigger governments. Moreover, since trade taxes are easier to collect, especially in developing countries, a positive relationship between trade openness and revenues can be expected. However, higher trade openness, measured by the share of imports and exports to GDP, could be the result of trade liberalization through tariff reduction. This would be consistent with a negative relationship between trade openness and revenue.

Other relevant control variables are included for additional robustness. They include inflation, which may have revenue effects through both unindexed tax systems and the generation of seigniorage; the level of external indebtedness, which reflects the need to generate revenue to service debt; and quality of institutions as proxied by the ICRG corruption index, which takes values from 0 (high corruption) to 6 (low corruption). We also 
include a dummy variable for oil exporter countries ${ }^{7}$ to capture the potential negative impact of natural resource revenues on domestic tax effort.

\section{B. Estimation}

Equation (1) is first estimated by ordinary least squares with country and time fixed-effects (OLS-FE). However, this method does not effectively deal with the potential endogeneity of the aid variable. In general, countries with the lowest tax-to-GDP ratio are also the largest aid-recipients. Moreover, aid can be tied to tax reform (such as tariff liberalization). Second, the characteristics of the tax revenue data, which show persistence over time, raise the possibility of serial correlation. ${ }^{8}$

To address these issues, results are reported for the fixed effects ${ }^{9}$ as well as two additional estimators: the difference and the system generalized method of moments (GMM). ${ }^{10}$ The difference-GMM estimator takes differences in Eq.(1) to remove the fixed effects such that, in the absence of serial correlation, instruments based on second and more lags of ODA are valid. The system-GMM estimates the differenced and levels equations as a system, using lagged changes as instruments in the latter. The resulting system-GMM estimator has much better finite sample properties in terms of bias and root mean squared error than that of the difference-GMM estimator. In cases in which instrument proliferation appears to be an issue, not only the Hansen statistic is reported for GMM estimators, but also the Sargan statistic, which is less vulnerable to instrument proliferation (Roodman, 2009). ${ }^{11}$

\footnotetext{
${ }^{7}$ Another important aspect would be to extend our analysis to non-resource tax revenues only as resource revenues can displace non resource tax revenues (see, for example, Bornhorst, Gupta, and Thornton, 2009). Unfortunately, data on resource-related revenues is limited and cannot always be broken down into tax and nontax components.

${ }^{8}$ This is confirmed by the Wooldrige test for serial correlation.

${ }^{9}$ Hausman tests favor the fixed effects over the random effects estimator, so the latter are not reported. Both Chow (1960), and Roy (1957), Zellner (1962), and Baltagi (2008) tests for poolability support the panel specification with homogeneous (not country-specific) slope coefficients, since the joint significance of the interactions between regressors and country dummies is rejected.

${ }^{10}$ Endogeneity could also be deal with by using an instrumental variable estimation, but finding suitable instruments for foreign aid is difficult. Therefore, using a GMM methodology is a better option.

11 The Hansen statistic's p-value should be high enough to reject correlation between the instruments and the errors but not too high because it weakens confidence in the test. The Sargan test, in contrast, is less vulnerable to instrument proliferation, but not robust to heteroskedasticity.
} 


\section{Data}

The dataset comprises 118 countries for the period 1980-2009. Data on tax revenue are drawn from the Government Financial Statistics (GFS) as well as from the annual consultation reports of the IMF with its member countries. ${ }^{12}$ The consultation reports were used to fill gaps in the GFS series and to ensure consistency. This data are further disaggregated into different components of tax revenues. Data on aid were collected from the OECD/DAC. Full details of the dataset and summary statistics are provided in Appendix I.

Figure 2 displays the relationship between different components of tax revenues and aid during the period 1980-2009. Total ODA is negatively associated with income taxes, VAT, and excise taxes, while trade taxes show a different picture. In addition, Figure A1.1 in Appendix I shows pairwise correlations between tax revenue and ODA grants for all countries in the sample. For about 70 percent of the countries, the correlation between the two variables is negative. Several studies have highlighted the possibility of differences in the taxation-aid relationship, depending on the type of tax (Gambaro et al., 2007; Carter, 2011). Two explanations are commonly put forward to explain the positive relationship between ODA and trade taxes. First, to the extent that ODA facilitate higher imports and that those are not tax-exempt, an increase in ODA will be positively associated with trade taxes. Second, a positive relationship between trade taxes and ODA may reflect omitted variables. In particular, a positive coefficient on ODA may reflect weak tax administration capacity which typically characterizes countries with a heavy reliance on trade taxes.

\footnotetext{
${ }^{12}$ See Baunsgaard and Keen (2010) for a detailed explanation of difficulties with GFS database on tax revenue.
} 
Figure 2. Average Taxes and Total Net ODA, 1980-2009 (percent of GDP)
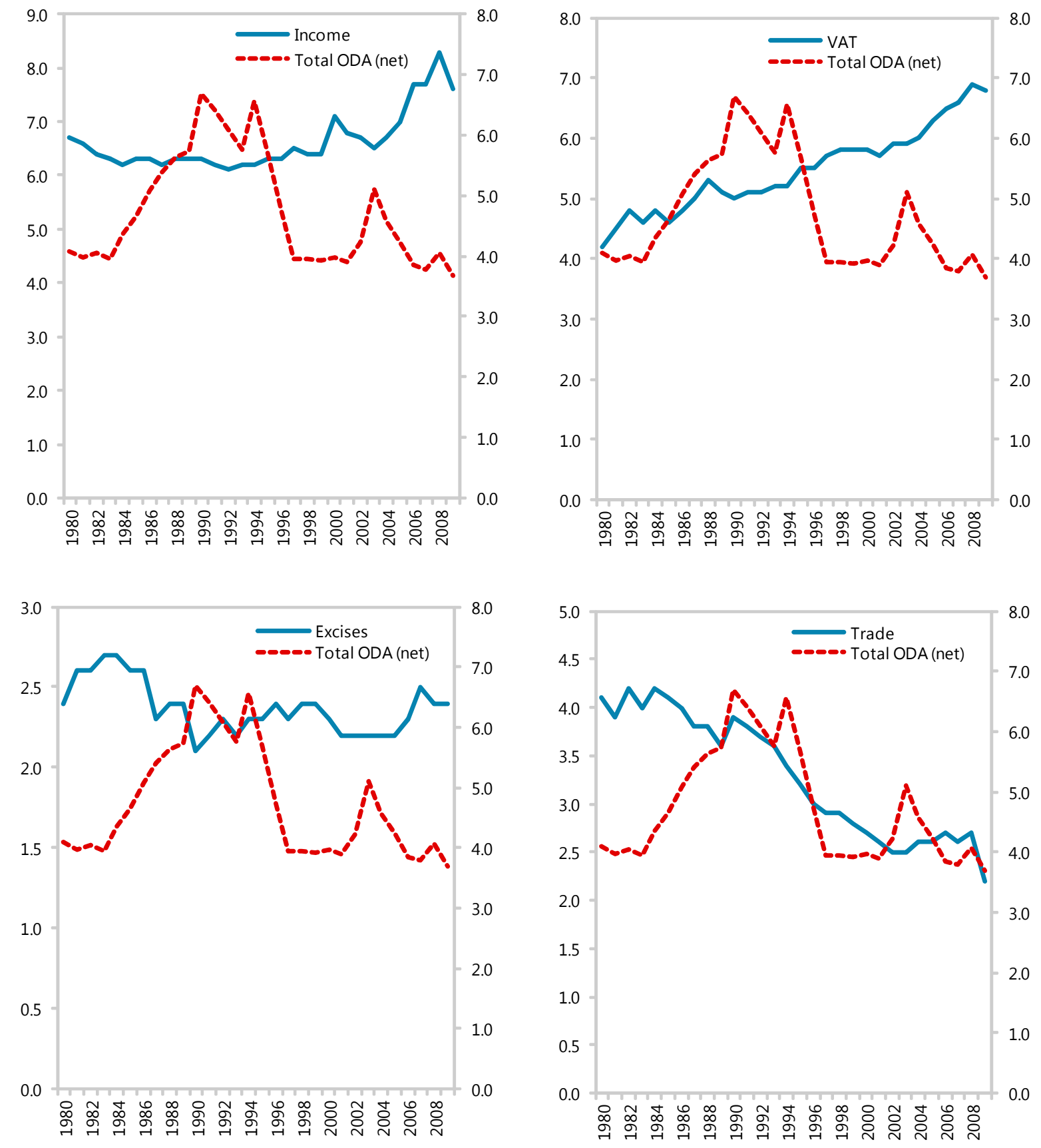

Source: Author's calculations based on the IMF's FAD Revenue Mobilization database and OECD DAC database. 


\section{Results}

\section{Total tax revenues}

This section reports the results of estimating equation (1) for total tax revenue, using the three methods discussed in Section III. Table 1 presents the results of our baseline model, in which only the main control variables are included, that is, the share of agriculture in valueadded, share of industry in value-added, GDP per capita, and trade openness. Also included are a full set of year dummies. The explanatory variable in the first specification is total net ODA (Model 1, Columns 1-3), whereas the second specification decomposes it into ODA loans and grants (Model 2, Columns 4-6).

Turning first to the control variables, we confirm that the structure of the economy matters for tax revenues. The share of agriculture in GDP is negatively related to revenues, whereas the share of industrial value added exhibits a positive relationship. The overall level of development, proxied by GDP per capita is, when significant, positively related to tax revenues. Trade openness, by contrast, is negatively related.

Our results on the association between aid and tax revenue confirm earlier findings in the literature. An increase in net ODA is associated with a statistically significant decline in total tax revenue. The results for the fixed effects specification suggest that for each additional dollar of total net $O D A$, there is an offset of 10 cents through lower tax revenues. ${ }^{13}$

Columns 2-3 present the results using the difference- and system-GMM estimators, respectively. The diagnostics are satisfactory, with the Arellano-Bond (1991) test for firstand second-order serial correlation (M1 and M2) suggesting that, consistent with the underlying assumptions, the former is present but the latter is not, or no serial correlation is present. Also the Hansen statistic seems tolerable. The negative impact of ODA on tax revenue becomes larger in these equations. For each additional dollar of total net ODA, there is an offset of about 20 cents through lower tax revenues (with system-GMM).

\footnotetext{
${ }^{13}$ This estimate is based on the regression coefficients reported in Column 1 in Table land the average value of total tax revenues (about 16 percent of GDP). Recall that we have a semi-log regression where the dependent variable (revenue ratio) is expressed in logs, whereas the aid variable is net ODA expressed as a ratio of GDP.
} 
Table 1. Net ODA Grants and Loans and Total Tax Revenues

\begin{tabular}{|c|c|c|c|c|c|c|}
\hline & \multicolumn{3}{|c|}{ Model 1} & \multicolumn{3}{|c|}{ Model 2} \\
\hline & (1) & $(2)$ & (3) & (4) & (5) & (6) \\
\hline & $\begin{array}{c}\text { Fixed } \\
\text { Effects }\end{array}$ & $\begin{array}{c}\text { Difference } \\
\text { GMM 1/ }\end{array}$ & $\begin{array}{l}\text { System } \\
\text { GMM 2/ }\end{array}$ & $\begin{array}{c}\text { Fixed } \\
\text { Effects }\end{array}$ & $\begin{array}{c}\text { Difference } \\
\text { GMM 1/ }\end{array}$ & $\begin{array}{l}\text { System } \\
\text { GMM 2/ }\end{array}$ \\
\hline & & & & & 0.1248 & $0.6655^{\star * *}$ \\
\hline \multirow[t]{2}{*}{ Tax, lagged } & & -0.0589 & $0.5882^{* * *}$ & & & \\
\hline & & $(0.02804)$ & $(0.0862)$ & & $(0.1476)$ & $(0.0672)$ \\
\hline \multirow[t]{2}{*}{ Total ODA } & $-0.0066^{*}$ & $-0.0216^{*}$ & $-0.0117^{*}$ & & & \\
\hline & $(0.0039)$ & $(0.0115)$ & $(0.0071)$ & & & \\
\hline \multirow[t]{2}{*}{ Total ODA, squared } & 0.0001 & $0.0002^{*}$ & 0.0001 & & & \\
\hline & $(0.0001)$ & $(0.0001)$ & $(0.0001)$ & & & \\
\hline \multirow[t]{2}{*}{ ODA Loans } & & & & 0.0001 & 0.0049 & 0.0142 \\
\hline & & & & $(0.0040)$ & $(0.0108)$ & $(0.0176)$ \\
\hline \multirow[t]{2}{*}{ ODA Loans, squared } & & & & -0.0000 & $-0.0018^{*}$ & -0.0011 \\
\hline & & & & $(0.0002)$ & $(0.0009)$ & $(0.0010)$ \\
\hline \multirow[t]{2}{*}{ ODA Grants } & & & & $-0.0055^{*}$ & $-0.0203^{* * *}$ & $-0.0151^{* * *}$ \\
\hline & & & & $(0.0032)$ & $(0.0067)$ & $(0.0010)$ \\
\hline \multirow[t]{2}{*}{ ODA Grants, squared } & & & & 0.0000 & $0.0002^{\star * *}$ & $0.0002^{* *}$ \\
\hline & & & & $(0.0000)$ & $(0.0001)$ & $(0.0001)$ \\
\hline \multirow[t]{2}{*}{$\begin{array}{l}\text { Agriculture share in } \\
\text { Value-Added }\end{array}$} & $-0.0080^{* * *}$ & -0.0028 & $-0.0173^{* *}$ & -0.0026 & -0.0057 & -0.0112 \\
\hline & $(0.0015)$ & $(0.0153)$ & $(0.0080)$ & $(0.0028)$ & $(0.0084)$ & $(0.0112)$ \\
\hline \multirow[t]{2}{*}{$\begin{array}{l}\text { Industry share in Value- } \\
\text { Added }\end{array}$} & 0.0003 & -0.0134 & -0.0256 & 0.0002 & 0.0045 & -0.0067 \\
\hline & $(0.0028)$ & $(0.0161)$ & $(0.0184)$ & $(0.0002)$ & $(0.0097)$ & $(0.0136)$ \\
\hline \multirow[t]{2}{*}{ GDP Per Capita (log) } & $0.3037^{* * *}$ & -0.0052 & -0.1552 & $0.3050^{* * *}$ & 0.0466 & -0.1283 \\
\hline & $(0.1222)$ & $(0.5752)$ & $(0.1413)$ & $(0.1222)$ & $(0.3592)$ & $(0.1515)$ \\
\hline \multirow[t]{2}{*}{ Trade Openness } & $-0.0020^{* *}$ & $-0.0073^{*}$ & -0.0045 & $-0.0019^{* *}$ & $-0.0053^{* *}$ & $-0.0065^{* *}$ \\
\hline & $(0.0009)$ & $(0.0043)$ & $(0.0030)$ & $(0.0009)$ & $(0.0022)$ & $(0.0032)$ \\
\hline \multirow[t]{2}{*}{ Constant } & $-0.6849^{* * *}$ & & & $-0.6997^{* * *}$ & & \\
\hline & $(0.1661)$ & & & $(0.1662)$ & & \\
\hline M1 ( $p$ value) & & 0.782 & 0.028 & & 0.105 & 0.012 \\
\hline M2 ( $p$ value) & & 0.254 & 0.793 & & 0.327 & 0.772 \\
\hline Over-identification & & Hansen: & Hansen: & & Hansen: & Hansen: \\
\hline ( $p$ value) & & 0.82 & 0.71 & & 0.87 & 0.60 \\
\hline Observations & 2589 & 2363 & 2376 & 2589 & 2363 & 2376 \\
\hline Number of instruments & & 54 & 57 & & 81 & 84 \\
\hline Number of countries & 118 & 116 & 117 & 118 & 116 & 117 \\
\hline
\end{tabular}

Note: Dependent variable is total tax revenue to GDP. Control variables include the share of agriculture in value-added, share of industry in value-added, GDP per capita and trade openness. Full set of year dummies in all regressions. Robust standard errors, in parenthesis; ${ }^{* * *}\left({ }^{* *},{ }^{*}\right)$ indicate significance at $1(5,10)$ percent.

1/ Two step, robust, instruments based on second lags of tax and ODA.

2/ Two step, robust, with instruments based on first lag of differences in tax and ODA in levels equation, and second lags of their levels in the differenced equation. 
Model 2 shows that the composition of ODA matters for total tax revenue. While ODA provided in the form of grants appears to be significantly associated with lower total tax revenues in all model specifications, aid offered in the form of loans is not. Model 2 suggests that each additional dollar in grants is offset by about 9 cents of tax revenues, based on the fixed effects specification, and by about 24 cents, according to the system-GMM estimator. Finally, the non-linear effect, captured by the inclusion of the squared ODA variables, shows the opposite sign in most of the regressions, meaning that as grants exceed a certain threshold, their impact on tax collection diminishes.

While these results not strictly comparable with Gupta et al. (2004) given differences in the country and time coverage of the dependent variable, the fixed-effects estimator (upon which previous results are based) seem to indicate a weakening effect of grants on incentives to mobilize domestic revenues. Whereas the previous study finds an offsetting effect on total revenue of about 28 cents for each additional dollar in grants, we obtain an offsetting effect of about 9 cents when using similar econometric techniques. This would be consistent with evidence of the strengthened efforts by developing countries to mobilize revenue through tax policy and tax administration reforms (see, for example IMF, 2011). The tax offset is higher under GMM estimators but still somewhat lower than estimated in the above-mentioned study.

Indeed, one way to deal with the potential negative consequences of ODA and/or grants on revenues is for countries to establish revenue benchmarks in their reform programs. Brun et al. (2011) show that IMF-supported programs have a positive impact on revenue mobilization and suggest that greater reliance on structural benchmarks in these programs improves revenue performance. It seems that countries are indeed moving in this direction at least when reviewing the number of revenue-related structural benchmarks in Fundsupported programs in low-income countries. Figure 3 shows that such benchmarks have increased since 2002-03. These benchmarks have included measures such as the introduction of a tax identification number, establishing a large tax payer unit, and increasing the VAT threshold. Given that the available data only covers the period 2002-11, it is not possible to empirically test the statistical significance of revenue benchmarks on the tax ratio. 
Figure 3. Structural Benchmarks and Indicative Targets in IMF-Supported Programs

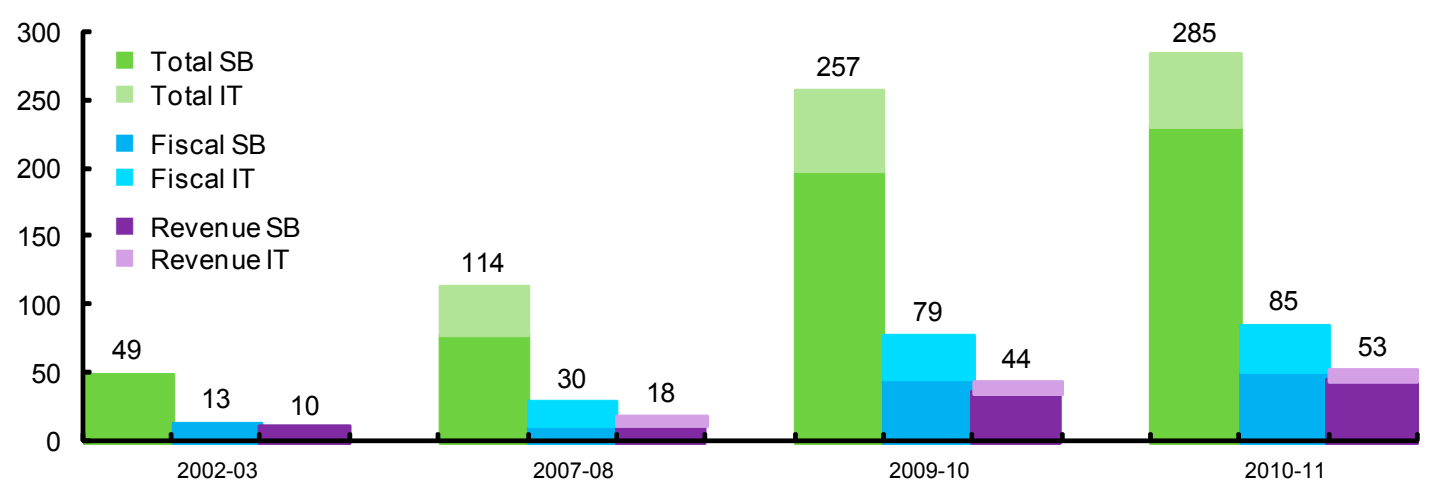

Source: IMF.

Notes: Indicative targets refer to quantitative targets that the program is designed to achieve, but is not a prerequisite for continued disbursements, e.g., fiscal deficit, floor on revenues, floor on priority spending.

Structural benchmarks (SB) can be legal, institutional, or policy measures that are relevant for a program's macroeconomic objectives, e.g., introduction of tax identification number, increase of VAT threshold, establishment of a large taxpayer unit, or reduction/elimination of tax exemption.

Programs include ECF, ECF-EFF, PRGF, PRGF-EFF, and PSI.

The next robustness test consisted of including additional control variables to Models 1 and 2. We added in addition to the previously considered controls, inflation, a dummy for oil exporters, the level of external indebtedness, and the index reflecting the level of corruption. The results — which are qualitatively similar to those presented in Table 1 - are presented in Appendix II.

\section{Disaggregation by tax type}

To empirically test for a differential relationship between ODA and taxes, we decompose tax revenues into VAT, excises, income, and trade taxes. For this purpose, only difference- and system-GMM estimates are reported. The full set of control variables as well as year dummies are included in all regressions. Table 2 summarizes the estimated coefficients by revenue type. In all cases, diagnostics are satisfactory, with a tolerable value for the Hansen/Sargan tests, and with the Arellano-Bond (1991) test for first- and second-order serial correlation (M1 and M2) suggesting that, consistent with the underlying assumptions, the former is present but the latter is not, or no serial correlation is present.

Similar to total tax revenue, net ODA has a negative relationship with VAT, excises, and income tax revenues. The composition of ODA matters. Grants are negatively associated with these taxes in almost all specifications. Coefficients for ODA loans are either positive or not significant for all four tax categories. As expected, trade taxes behave differently. Total ODA is found to be positively associated with trade tax revenue and the same holds for ODA loans and ODA grants separately. This confirms the hypothesis that increased aid facilitates higher imports, thus contributing to higher revenues from trade taxes. 
Table 2. Effect of Net ODA Grants and Loans on Each Type of Tax Revenue

\begin{tabular}{|c|c|c|c|c|}
\hline & \multicolumn{2}{|c|}{ VAT } & \multicolumn{2}{|c|}{ Trade Taxes } \\
\hline & (1) & (2) & (1) & (2) \\
\hline & $\begin{array}{l}\text { Difference } \\
\text { GMM 1/ }\end{array}$ & $\begin{array}{l}\text { System } \\
\text { GMM 2/ }\end{array}$ & $\begin{array}{c}\text { Difference GMM } \\
1 /\end{array}$ & $\begin{array}{l}\text { System } \\
\text { GMM 2/ }\end{array}$ \\
\hline \multicolumn{5}{|l|}{ Model 1: } \\
\hline \multirow[t]{2}{*}{ Tax, lagged } & $0.6726^{* *}$ & 0.457 & $0.6382^{* * *}$ & $0.7604^{* * *}$ \\
\hline & $(0.3245)$ & $(0.966)$ & $(0.1034)$ & $(0.0645)$ \\
\hline \multirow[t]{2}{*}{ ODA Total } & $-0.2831^{* *}$ & $-0.3205^{\star * *}$ & $0.0327^{\star *}$ & $0.0281^{* *}$ \\
\hline & $(0.1203)$ & $(0.0115)$ & $(0.0157)$ & $(0.0123)$ \\
\hline \multirow[t]{2}{*}{ ODA Total, squared } & $0.0076^{\star * *}$ & $0.0152^{\star \star \star}$ & $-0.0003^{* *}$ & $-0.0002^{* * *}$ \\
\hline & $(0.0020)$ & $(0.0007)$ & $(0.0001)$ & $(0.0001)$ \\
\hline M1 ( $p$ value) & 0.012 & 0.277 & 0.006 & 0.014 \\
\hline M2 ( $p$ value) & 0.214 & 0.277 & 0.598 & 0.232 \\
\hline Over-identification & Hansen: 1.00 & Hansen: 1.00 & Hansen: 1.00 & Hansen: \\
\hline ( $p$ value) & Sargan: 0.49 & Sargan: 0.89 & Sargan: 0.06 & 0.65 \\
\hline Observations & 345 & 349 & 1226 & 1307 \\
\hline Number of instruments & 46 & 49 & 92 & 94 \\
\hline \multicolumn{5}{|l|}{ Model 2: } \\
\hline \multirow[t]{2}{*}{ Tax, lagged } & $0.3262^{\star * *}$ & $0.2048^{*}$ & $0.3836^{\star * *}$ & $0.8107^{* * *}$ \\
\hline & $(0.1178)$ & $(0.1202)$ & $(0.1438)$ & $(0.0318)$ \\
\hline \multirow[t]{2}{*}{ ODA Loans } & 0.0499 & 0.0487 & 0.0041 & $0.0293^{*}$ \\
\hline & $(0.0395)$ & $(0.0389)$ & $(0.0350)$ & $(0.0158)$ \\
\hline \multirow[t]{2}{*}{ ODA Loans, squared } & 0.0044 & 0.0048 & -0.0044 & $-0.0022^{*}$ \\
\hline & $(0.0038)$ & $(0.0037)$ & $(0.0027)$ & $(0.0013)$ \\
\hline \multirow[t]{2}{*}{ ODA Grants } & $-0.1012^{* \star \star}$ & $-0.1139^{\star \star}$ & -0.0195 & -0.0026 \\
\hline & $(0.0385)$ & $(0.0516)$ & $(0.0196)$ & $(0.0084)$ \\
\hline \multirow[t]{2}{*}{ ODA Grants, squared } & $0.0041^{* *}$ & $0.0045^{\star *}$ & $0.0004^{*}$ & $0.0002^{*}$ \\
\hline & $(0.0017)$ & $(0.0018)$ & $(0.0002)$ & $(0.0001)$ \\
\hline M1 ( $p$ value) & 0.271 & 0.107 & 0.038 & 0.008 \\
\hline M2 ( $p$ value) & 0.196 & 0.334 & 0.594 & 0.128 \\
\hline Over-identification & Hansen: 1.00 & Hansen: 1.00 & Hansen: & Hansen: \\
\hline ( $p$ value) & Sargan: 0.13 & Sargan: 0.08 & 0.82 & 0.27 \\
\hline Observations & 345 & 349 & 1226 & 1307 \\
\hline Number of instruments & 69 & 72 & 69 & 142 \\
\hline Number of countries & 51 & 51 & 71 & 71 \\
\hline
\end{tabular}

Note: Dependent variable is total tax revenue to GDP. Full set of year dummies in all regressions. Robust standard errors, in parenthesis; ${ }^{* * *}\left({ }^{* *},{ }^{*}\right)$ indicate significance at $1(5,10)$ percent.

1/ For Model 1, two step, robust; for Model 2, one step, robust; instruments based on second lags of tax and ODA.

2/ For Model 1, two step, robust; for Model 2, one step, robust; with instruments based on first lag of differences in tax and ODA in levels equation, and second lags of their levels in the differenced equation. 
Table 2. Effect of Net ODA Grants and Loans on Each Type of Tax Revenue (concluded)

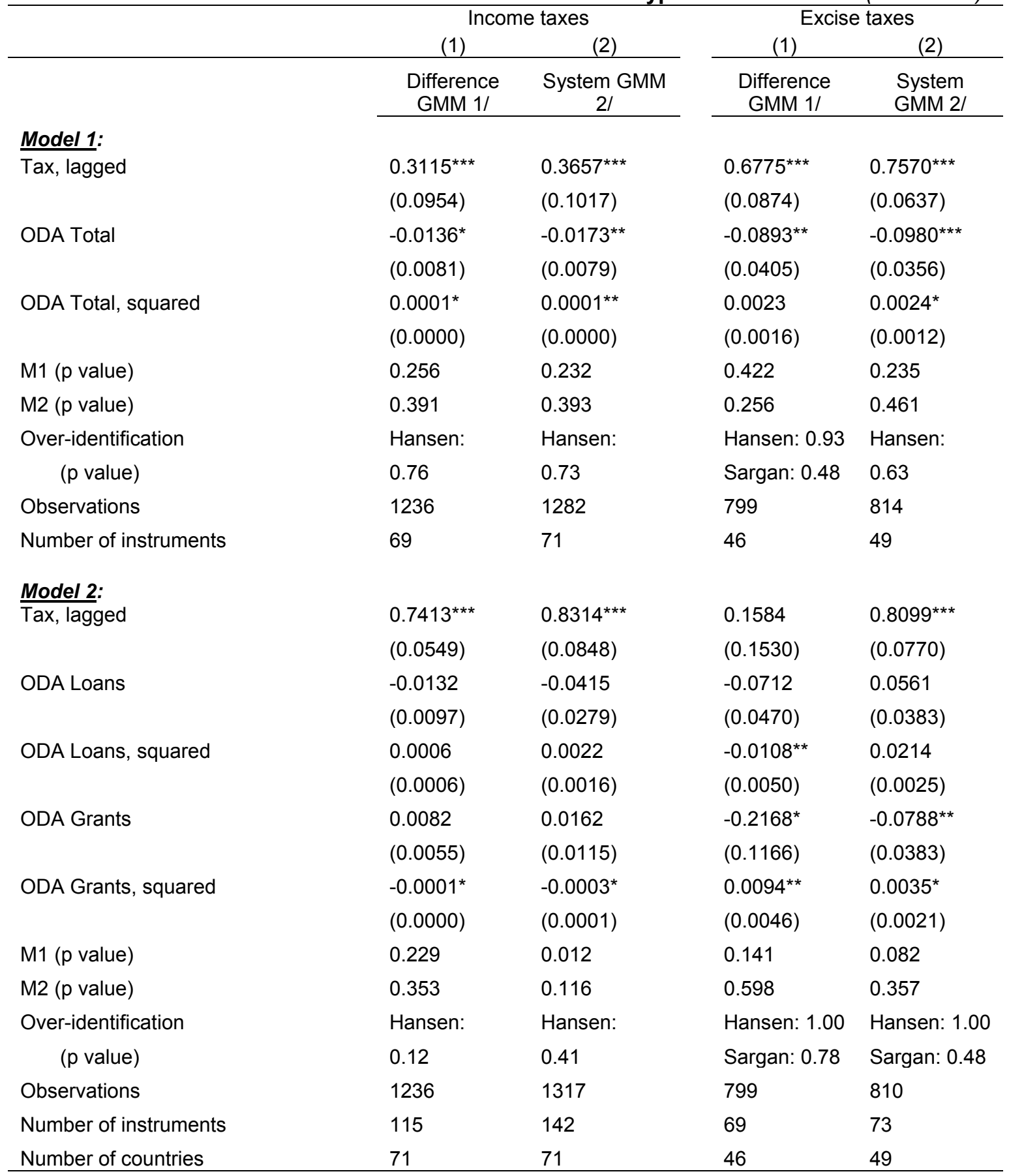

Notes: Dependent variable is total tax revenue to GDP. Full set of year dummies in all regressions. Robust standard errors, in parenthesis; ${ }^{* * *}\left({ }^{* *},{ }^{*}\right)$ indicate significance at $1(5,10)$ percent.

1/ For model 1, two step, robust; for model 2, one step, robust; instruments based on second lags of tax and ODA.

2/ For model 1, two step, robust; for model 2, one step, robust; with instruments based on first lag of differences in tax and ODA in levels equation, and second lags of their levels in the differenced equation. 
Estimated coefficients are larger in magnitude than those for total taxes (see Appendix III for details). Using average values for ODA grants and the relevant tax type, we obtain revenue offsets for an additional dollar of ODA grants of 47 cents for the VAT, and 14 cents for excises. While still negative, the offsets for income taxes are very small. For trade taxes, there is a small positive relationship associated with aid. As the sample of countries with disaggregated tax revenues is smaller than the full sample, the results from different tax types are not comparable with econometric estimates presented in Table 1. The high offset for the VAT could reflect exemptions from tax that donors get for donor-supported outlays. This also applies to import duties, but higher private sector imports facilitated by ODA appear to overwhelm this effect.

The results in Table 2 are not surprising. Notably for VAT, recent estimates indicate a potential for raising additional revenue in developing countries by about 2 percent of GDP, on average. ${ }^{14}$ This is reflected in relatively low VAT efficiency (that is, the ratio of VAT revenue in percent of total consumption to the standard VAT rate) in many low- and lowmiddle income countries, suggesting not only poor VAT design but also its imperfect compliance. Similarly, there has been a proliferation of investment incentives over the past thirty years, particularly in sub-Saharan Africa. In the 1980s, some 40 percent of the lowincome countries in the region offered tax holidays; this number doubled by 2005 (Keen and Mansour, 2010a and 2010b). The provision of incentives in many countries is a reflection of poor governance (IMF, 2011). Estimates of revenue loss from tax exemptions vary. For example, the budgetary cost of preferential treatments is estimated to range between 0.5 to 6 percent of GDP in Latin America (Villela, Lemgruber, and Jorratt, 2010).

\section{Disaggregation by Income Groups}

We test our baseline model on three country groups based on their income level: low, lowermiddle, and upper-middle income country groups. ${ }^{15}$ Again, only difference- and systemGMM estimates are reported (Table 3). ${ }^{16}$

\footnotetext{
${ }^{14}$ Also for excise taxes, IMF (2011) estimates a potential to increase revenues by between 0.5 and 1.3 percent of GDP in developing countries, on average.

${ }^{15}$ Countries are grouped following the World Bank classification which divides countries according to the 2009 gross national income (GNI per capita), calculated using the World Bank Atlas Method. The groups are: lowincome, $\$ 995$ or less; lower middle-income, $\$ 996-3,945$; upper middle-income, $\$ 3,946-12,195$; and highincome, $\$ 12,196$ or more.

${ }^{16}$ Diagnostics for the GMM estimators are satisfactory, with tolerable value for the Hansen/Sargan tests, and with Arellano-Bond (1991) tests showing no presence of serial correlation. This information has been omitted from Table 3 to preserve space.
} 
For total ODA, the results show a significantly negative relation to tax revenue for all income groups. When aid is separated into loans and grants, however, the estimated coefficients are statistically significant only for low-income countries.

Table 3. Effect of ODA on Total Tax Revenue by Countries' Income Level

\begin{tabular}{|c|c|c|c|c|c|c|}
\hline & \multicolumn{2}{|c|}{ Low income } & \multicolumn{2}{|c|}{ Lower-middle income } & \multicolumn{2}{|c|}{ Upper-middle income } \\
\hline & (1) & (2) & (1) & (2) & (1) & (2) \\
\hline & $\begin{array}{c}\text { Difference } \\
\text { GMM 1/ }\end{array}$ & $\begin{array}{l}\text { System } \\
\text { GMM 2/ }\end{array}$ & $\begin{array}{c}\text { Difference } \\
\text { GMM 1/ }\end{array}$ & $\begin{array}{l}\text { System } \\
\text { GMM 2/ }\end{array}$ & $\begin{array}{c}\text { Difference } \\
\text { GMM 1/ }\end{array}$ & $\begin{array}{l}\text { System } \\
\text { GMM 2/ }\end{array}$ \\
\hline \multicolumn{7}{|l|}{ Model 1: } \\
\hline \multirow[t]{2}{*}{ Total ODA } & -0.0086 & $-0.0088^{* * *}$ & $-0.0722^{\star *}$ & 0.0034 & $-0.0675^{*}$ & 0.0028 \\
\hline & $(0.0085)$ & $(0.0034)$ & $(0.0324)$ & $(0.0596)$ & $(0.0420)$ & $(0.0123)$ \\
\hline \multirow[t]{2}{*}{ Total ODA, squared } & 0.0000 & -0.0001 & $0.0013^{*}$ & -0.0001 & $0.0024^{*}$ & -0.0005 \\
\hline & $(0.0000)$ & $(0.0004)$ & $(0.0007)$ & $(0.0017)$ & $(0.0013)$ & $(0.0005)$ \\
\hline \multicolumn{7}{|l|}{ Model 2: } \\
\hline \multirow[t]{2}{*}{ ODA Loans } & 0.0024 & 0.0462 & -0.0289 & 0.0165 & -0.0227 & 0.0018 \\
\hline & $(0.0088)$ & $(0.0454)$ & $(0.0239)$ & $(0.0543)$ & $(0.0174)$ & $(0.0111)$ \\
\hline \multirow[t]{2}{*}{ ODA Loans, squared } & -0.0008 & $-0.0097^{\star \star}$ & -0.0021 & 0.0133 & -0.0031 & 0.0038 \\
\hline & $(0.0007)$ & $(0.0042)$ & $(0.0032)$ & $(0.0238)$ & $(0.0077)$ & $(0.0029)$ \\
\hline \multirow[t]{2}{*}{ ODA Grants } & $-0.0148^{*}$ & $-0.0803^{* *}$ & $-0.0414^{*}$ & -0.0570 & -0.0512 & 0.0043 \\
\hline & $(0.0095)$ & $(0.0399)$ & $(0.0262)$ & $(0.0411)$ & $(0.0339)$ & $(0.0113)$ \\
\hline \multirow[t]{2}{*}{ ODA Grants, squared } & $0.0001^{*}$ & $0.0013^{* *}$ & 0.0007 & -0.0009 & $0.0019^{*}$ & -0.0005 \\
\hline & $(0.0001)$ & $(0.0005)$ & $(0.0005)$ & $(0.0007)$ & $(0.0011)$ & $(0.0005)$ \\
\hline Observations & 737 & 769 & 833 & 884 & 769 & 808 \\
\hline Number of Countries & 34 & 34 & 43 & 44 & 38 & 38 \\
\hline
\end{tabular}

Note: Dependent variable is total tax revenue to GDP. Control variables include the share of agriculture in value-added, share of industry in value-added, GDP per capita, trade openness, inflation, and external debt. Full set of year dummies in all regressions. Robust standard errors, in parenthesis; ${ }^{* * *}\left({ }^{* *},{ }^{*}\right)$ indicate significance at $1(5,10)$ percent.

$1 /$ One step, robust, with instruments based on second lags of tax and ODA.

2/ Two step, robust, with instruments based on first lag of differences in tax and ODA in levels equation, and second lags of their levels in the differenced equation. 


\section{Disaggregation by geographical regions}

We disaggregate our sample into five regions: Africa; Asia and the Pacific; Europe; Middle East and Central Asia; and Western Hemisphere. Table 4 presents the results. ${ }^{17}$ For total ODA and ODA grants, the results show a negative relationship with tax revenues in Africa, and Asia and Pacific, with both difference- and system-GMM estimators. For the Western Hemisphere region, the non-linear effect on grants indicates that relatively large aid inflows affect the incentives to mobilize taxes. For ODA loans, only in Africa do we find a significantly negative relationship with tax revenues.

\section{Strength of country's institutions}

We now turn to assess whether the effect of aid on tax revenues is influenced by country's institutions. To do so, we split the sample on the basis of the ICRG ranking of corruption. This ranking is taken as a proxy for the strength of a country's institutions. Countries are grouped into quartiles on the basis of the ICRG index. Total tax revenues of countries that fall in the $25^{\text {th }}$ and $50^{\text {th }}$ percentile (i.e., those with the weakest institutions) are respectively regressed on the same explanatory variables as before.

The results are presented in Table $5 .^{18}$ As is the case for the full sample, our results show that for countries falling in the bottom two quartiles, the coefficient estimates on ODA grants are significantly negatively signed. For the bottom quartile of corrupt countries, this effect is particularly strong: there is almost complete revenue offset on each additional dollar of net ODA. Moreover, there is a negative association between ODA loans and tax revenue.

\footnotetext{
${ }^{17}$ Also here, the diagnostics for the GMM estimators are satisfactory, with tolerable value for the Hansen/Sargan tests, and with Arellano-Bond (1991) tests showing no presence of serial correlation. This information has been omitted from Table 4 to preserve space.

${ }^{18}$ Also here, the diagnostics for the GMM estimators appear satisfactory, with tolerable value for the Hansen/Sargan tests, and with Arellano-Bond (1991) tests showing no presence of serial correlation. This information has been omitted from Table 5 to preserve space.
} 
Table 4. Effect of ODA on Total Tax Revenue by Region

\begin{tabular}{|c|c|c|c|c|c|c|c|c|c|c|}
\hline & \multicolumn{2}{|c|}{ Africa } & \multicolumn{2}{|c|}{ Asia \& Pacific } & \multicolumn{2}{|c|}{ Europe } & \multicolumn{2}{|c|}{ Middle East } & \multicolumn{2}{|c|}{ Western Hemisphere } \\
\hline & $(1)$ & $(2)$ & $(1)$ & $(2)$ & $(1)$ & $(2)$ & & $(2)$ & & \\
\hline & $\begin{array}{c}\text { Difference } \\
\text { GMM 1/ }\end{array}$ & $\begin{array}{l}\text { System } \\
\text { GMM 2/ }\end{array}$ & $\begin{array}{c}\text { Difference } \\
\text { GMM 1/ }\end{array}$ & $\begin{array}{l}\text { System } \\
\text { GMM 2/ }\end{array}$ & $\begin{array}{c}\text { Difference } \\
\text { GMM 1/ }\end{array}$ & $\begin{array}{l}\text { System } \\
\text { GMM 2/ }\end{array}$ & $\begin{array}{c}\text { Difference } \\
\text { GMM 1/ }\end{array}$ & $\begin{array}{l}\text { System } \\
\text { GMM 2/ }\end{array}$ & $\begin{array}{c}\text { Difference } \\
\text { GMM 1/ }\end{array}$ & $\begin{array}{l}\text { System } \\
\text { GMM 2/ }\end{array}$ \\
\hline \multicolumn{11}{|l|}{ Model 1: } \\
\hline Total ODA & $\begin{array}{c}-0.0368^{*} \\
(0.0237)\end{array}$ & $\begin{array}{c}-0.1073^{* *} \\
(0.0496)\end{array}$ & $\begin{array}{c}-0.0474^{*} \\
(0.0259)\end{array}$ & $\begin{array}{c}-0.2946^{\star *} \\
(0.1556)\end{array}$ & $\begin{array}{r}-0.1703^{*} \\
0.0959)\end{array}$ & $\begin{array}{c}-0.0639^{* * *} \\
(0.0152)\end{array}$ & $\begin{array}{c}-0.0686 \\
(0.0752)\end{array}$ & $\begin{array}{l}-0.0192 \\
(0.1532)\end{array}$ & $\begin{array}{c}-0.0169 \\
(0.0190)\end{array}$ & $\begin{array}{l}0.4611 \\
(0.4367)\end{array}$ \\
\hline $\begin{array}{l}\text { Total ODA, squared } \\
\text { Model 2: }\end{array}$ & $\begin{array}{l}0.0003 \\
(0.0002)\end{array}$ & $\begin{array}{l}0.0020 \\
(0.0015)\end{array}$ & $\begin{array}{l}0.0009 \\
(0.0006)\end{array}$ & $\begin{array}{l}0.0031^{* *} \\
(0.0014)\end{array}$ & $\begin{array}{l}0.0142^{* * *} \\
(0.0054)\end{array}$ & $\begin{array}{l}0.0034^{* * *} \\
(0.0009)\end{array}$ & $\begin{array}{l}0.0025 \\
(0.0032)\end{array}$ & $\begin{array}{l}0.0010 \\
(0.0056)\end{array}$ & $\begin{array}{l}0.0010 \\
(0.0007)\end{array}$ & $\begin{array}{l}-0.0225 \\
(0.0222)\end{array}$ \\
\hline ODA Loans & $\begin{array}{l}0.0116 \\
(0.0133)\end{array}$ & $\begin{array}{l}-0.2453^{* *} \\
(0.1155)\end{array}$ & $\begin{array}{l}-0.0045 \\
(0.0225)\end{array}$ & $\begin{array}{l}-0.0851 \\
(0.0805)\end{array}$ & $\begin{array}{l}-0.1378 \\
(0.1188)\end{array}$ & $\begin{array}{l}0.2834^{* * *} \\
(0.0767)\end{array}$ & $\begin{array}{l}-0.0416 \\
(0.0376)\end{array}$ & $\begin{array}{l}0.0182 \\
(0.0237)\end{array}$ & $\begin{array}{l}-0.0110 \\
(0.0083)\end{array}$ & $\begin{array}{l}0.0026 \\
(0.0066)\end{array}$ \\
\hline $\begin{array}{l}\text { ODA Loans, } \\
\text { squared }\end{array}$ & $\begin{array}{l}-0.0021 \\
(0.0016)\end{array}$ & $\begin{array}{l}0.0265 \\
(0.0150)\end{array}$ & $\begin{array}{l}-0.0286^{*} \\
(0.0182)\end{array}$ & $\begin{array}{l}-0.0172 \\
(0.0279)\end{array}$ & $\begin{array}{l}-0.0652 \\
(0.1962)\end{array}$ & $\begin{array}{l}-0.2216^{* * *} \\
(0.0512)\end{array}$ & $\begin{array}{l}0.0036 \\
(0.0033)\end{array}$ & $\begin{array}{l}-0.0009 \\
(0.0023)\end{array}$ & $\begin{array}{l}-0.0022^{* * *} \\
(0.0007)\end{array}$ & $\begin{array}{l}0.0012^{*} \\
(0.0006)\end{array}$ \\
\hline ODA Grants & $\begin{array}{l}-0.0283^{*} \\
(0.0181)\end{array}$ & $\begin{array}{l}-0.1803^{* *} \\
(0.1080)\end{array}$ & $\begin{array}{l}-0.0286^{*} \\
(0.0182)\end{array}$ & $\begin{array}{r}-0.1342^{* *} \\
(0.0747)\end{array}$ & $\begin{array}{l}-0.2012^{* * *} \\
(0.0557)\end{array}$ & $\begin{array}{l}-0.0565^{\star * *} \\
(0.0089)\end{array}$ & $\begin{array}{l}-0.1826 \\
(0.1659)\end{array}$ & $\begin{array}{l}0.0079 \\
(0.0140)\end{array}$ & $\begin{array}{l}-0.0096 \\
(0.0239)\end{array}$ & $\begin{array}{l}0.0295 \\
(0.0187)\end{array}$ \\
\hline $\begin{array}{l}\text { ODA Grants, } \\
\text { squared }\end{array}$ & $\begin{array}{l}0.0003^{*} \\
(0.0002)\end{array}$ & $\begin{array}{l}0.0026 \\
(0.0020)\end{array}$ & $\begin{array}{l}0.0006^{*} \\
(0.0003)\end{array}$ & $\begin{array}{l}0.0025 \\
(0.0016)\end{array}$ & $\begin{array}{l}0.0151^{* * *} \\
(0.0050)\end{array}$ & $\begin{array}{l}0.0025^{\star * *} \\
(0.0008)\end{array}$ & $\begin{array}{l}0.0092 \\
(0.0081)\end{array}$ & $\begin{array}{l}-0.0003 \\
(0.0008)\end{array}$ & $\begin{array}{l}0.0006 \\
(0.0009)\end{array}$ & $\begin{array}{l}-0.0015^{\star *} \\
(0.0007)\end{array}$ \\
\hline $\begin{array}{l}\text { Observations } \\
\text { Number of } \\
\text { Countries }\end{array}$ & $\begin{array}{l}944 \\
42 \\
\end{array}$ & $\begin{array}{l}962 \\
41 \\
\end{array}$ & $\begin{array}{l}395 \\
19 \\
\end{array}$ & $\begin{array}{l}418 \\
20 \\
\end{array}$ & $\begin{array}{l}67 \\
7 \\
\end{array}$ & $\begin{array}{l}72 \\
7 \\
\end{array}$ & $\begin{array}{l}342 \\
20 \\
\end{array}$ & $\begin{array}{l}366 \\
20 \\
\end{array}$ & $\begin{array}{l}615 \\
28 \\
\end{array}$ & $\begin{array}{l}645 \\
28 \\
\end{array}$ \\
\hline
\end{tabular}

Note: Dependent variable is total tax revenue to GDP. Control variables include the share of agriculture in value-added, share of industry in value-added, GDP per capita, trade openness, inflation, external debt. Full set of year dummies in all regressions. Robust standard errors, in parenthesis; ${ }^{* * *}\left({ }^{* *},{ }^{*}\right)$ indicate significance at $1(5,10)$ percent.

$1 /$ One step, robust, instruments based on second lags of tax and ODA.

2/ Two step, robust, with instruments based on first lag of differences in tax and ODA in levels equation, and second lags of their levels in the differenced equation. For Europe, one step, robust. 
Table 5. Impact of ODA on Total Tax Revenue in Countries with Weak Institutions

\begin{tabular}{|c|c|c|c|c|}
\hline & \multicolumn{2}{|c|}{$50^{\text {th }}$ Percentile } & \multicolumn{2}{|c|}{$25^{\text {th }}$ Percentile } \\
\hline & $(1)$ & $(2)$ & $(1)$ & $(2)$ \\
\hline & $\begin{array}{c}\text { Difference } \\
\text { GMM 1/ }\end{array}$ & $\begin{array}{l}\text { System } \\
\text { GMM 2/ }\end{array}$ & $\begin{array}{c}\text { Difference } \\
\text { GMM 1/ }\end{array}$ & $\begin{array}{l}\text { System } \\
\text { GMM 2/ }\end{array}$ \\
\hline \multirow[t]{2}{*}{ ODA Loans } & -0.0030 & 0.0461 & $-0.0143^{* *}$ & $-0.0417^{* * *}$ \\
\hline & $(0.0136)$ & $(0.0452)$ & $(0.0068)$ & $(0.0061)$ \\
\hline \multirow[t]{2}{*}{ ODA Loans, squared } & 0.0001 & 0.0008 & 0.0003 & $0.0048^{* * *}$ \\
\hline & $(0.0006)$ & $(0.0005)$ & $(0.0005)$ & $(0.0016)$ \\
\hline \multirow[t]{2}{*}{ ODA Grants } & $-0.0210^{* *}$ & $-0.0412^{*}$ & $-0.0167^{\star *}$ & $-0.1081^{* *}$ \\
\hline & $(0.0108)$ & $(0.0220)$ & $(0.0075)$ & $(0.0554)$ \\
\hline \multirow[t]{2}{*}{ ODA Grants, squared } & 0.0001 & -0.0068 & 0.0001 & $0.0015^{\star}$ \\
\hline & $(0.0001)$ & $(0.0055)$ & $(0.0001)$ & $(0.0009)$ \\
\hline Observations & 766 & 809 & 333 & 355 \\
\hline Number of countries & 40 & 40 & 19 & 19 \\
\hline
\end{tabular}

Note: Dependent variable is total tax revenue to GDP. Control variables include the share of agriculture in value-added, share of industry in value-added, GDP per capita and trade openness. Full set of year dummies in all regressions. Robust standard errors, in parenthesis; ${ }^{* * *}\left({ }^{* *},{ }^{*}\right)$ indicate significance at $1(5,10)$ percent.

$1 /$ One step, robust, instruments based on second lags of tax and ODA.

2/ Two step, robust, with instruments based on first lag of differences in tax and ODA in levels equation, and second lags of their levels in the differenced equation. 


\section{CONCLUding REMARKS}

In this paper, we have employed a new dataset to re-examine the relationship between aid and tax revenues. Our results are in line with earlier findings which suggest the existence of a negative relationship between ODA grants and tax revenue. These results are robust to different model specifications, including those that consider potential endogeneity and serial correlation in the data. In addition, our results are reasonably robust across income levels and different geographical regions and appear to be stronger in low-income countries. However, they indicate that the impact of ODA grants on tax revenues appears to be weakening over time. While Gupta et al. (2004) found an offset of total revenue of about 28 cents for each additional dollar in grants, we find (using the comparable estimation method) tax revenue declining by 9 cents for each grant dollar. We believe that this negative impact of grants can be managed by the policymakers if adequate attention is paid to strengthening domestic revenue mobilization capacity. Indeed, the paper presents evidence of increased use of revenue benchmarks in many low-income countries to strengthen revenue performance.

Our analysis of disaggregated tax data shows that the relationship between ODA grants and certain taxes (VAT, income taxes, and excises) is also negative, except in the case of trade taxes. In the latter case, higher ODA grants are associated with rising tax revenue, reflecting increased imports made possible by rising external grants. In addition, we find that in countries with weak institutions, the increase in external grants is associated with an equivalent reduction in tax revenues. In these countries, both ODA grants and ODA loans have a negative impact on tax revenue-to-GDP ratio. This suggests that policymakers and donors need to pay particular attention to strengthening revenue raising capacity of these countries to ensure that ODA flows have a net additionality in resources. 


\section{Appendix I. Data}

The countries in the sample are the following:

Low-income countries: Bangladesh, Benin, Burkina Faso, Burundi, Cambodia, Central African Rep., Chad, Comoros, Congo, Dem. Rep. of, Eritrea, Ethiopia, The Gambia, Ghana, Guinea, Guinea-Bissau, Haiti, Kenya, Kyrgyz Republic, Lao People's Democratic Republic, Madagascar, Mali, Mauritania, Mozambique, Myanmar, Nepal, Niger, Rwanda, Sierra Leone, Solomon Islands, Tajikistan, Tanzania, Togo, Uganda, Zambia, Zimbabwe

Lower middle-income countries: Angola, Armenia, Belize, Bhutan, Bolivia, Cameroon, Cape Verde, China, P.R.: Mainland, Republic of Congo, Côte d'Ivoire, Djibouti, Egypt, Georgia, Guatemala, Guyana, Honduras, India, Indonesia, Jordan, Lesotho, Maldives, Moldova, Mongolia, Morocco, Nicaragua, Nigeria, Pakistan, Papua New Guinea, Paraguay, Philippines, Samoa, Senegal, Sri Lanka, Sudan, Swaziland, Syrian Arab Republic, São Tomé and Príncipe, Thailand, Tunisia, Ukraine, Uzbekistan, Vanuatu, Vietnam, Republic of Yemen

Upper middle-income countries: Albania, Algeria, Argentina, Republic of Azerbaijan, Belarus, Bosnia and Herzegovina, Botswana, Brazil, Bulgaria, Chile, Colombia, Dominica, Dominican Republic, Fiji, Gabon, Grenada, I.R. of Iran, Jamaica, Kazakhstan, Lebanon, Libya, Lithuania, Macedonia FYR, Malaysia, Mauritius, Mexico, Namibia, Panama, Peru, Russian Federation, Seychelles, South Africa, St. Kitts and Nevis, St. Lucia, St. Vincent and the Grenadines, Suriname, Turkey, Uruguay, Rep. Bol. Venezuela.

Data on total tax revenue, VAT, excises, income tax revenue, and trade tax revenue are taken from the IMF's Fiscal Affairs Department Database on Revenue Mobilization, the Government Financial Statistics (GFS) database, and IMF country documents, as discussed in Section III, relative to GDP. Net ODA, ODA_Grants, and ODA_Loans, relative to GDP, are from the OCDE (Development Co-operation Directorate) database. Share of agriculture in aggregate value added, as well as share of industry in aggregate value added, taken from the World Bank's World Development Indicators (WDI) database. Trade Openness is calculated as imports plus exports in percent of GDP, taken from the IMF's International Financial Statistics (IFS) database. Per capita GDP is calculated in constant (2000) U.S. dollars, taken from the WDI database, expressed in logs. Inflation is the annual change in the CPI, taken from the IFS database. Foreign debt, relative to GDP, taken from the WDI database. The ICRG corruption scores, produced by Political Risk Services Group, are assessments by staff and relate to actual and potential corruption in the following forms: excessive patronage, nepotism, job reservations, 'favor-for-favors', secret party funding and suspiciously close ties between politics and business. The scores range from 0 to 6 , where 0 indicates the highest potential risk of corruption and 6 indicates the lowest potential risk for any country. The oil exporter dummy, takes the value 1 when the country is a net oil exporter and 0 otherwise. Table A1.1 summarizes the data. 
Table A1.1. Descriptive Statistics

\begin{tabular}{lrrrrr}
\hline & Observations & Mean & Maximum & Minimum & Std. Dev. \\
\hline Total Tax Revenue, percent of GDP & 2728 & 16.08 & 61.50 & 0.10 & 7.55 \\
VAT Tax Revenue, percent of GDP & 764 & 4.51 & 16.00 & 0.00 & 2.72 \\
Income Tax Revenue, percent of GDP & 2650 & 4.68 & 50.60 & 0.00 & 4.01 \\
Excise Tax Revenue, percent of GDP & 1613 & 2.00 & 21.90 & 0.00 & 1.59 \\
Trade Tax Revenue, percent of GDP & 2615 & 4.01 & 41.80 & 0.00 & 4.09 \\
& & & & & \\
Total ODA, percent of GDP & 3322 & 4.72 & 96.30 & -2.96 & 6.27 \\
ODA Grants, percent of GDP & 3322 & 4.47 & 130.84 & 0.00 & 6.30 \\
ODA Loans, percent of GDP & 3322 & 0.25 & 26.38 & -34.54 & 1.49 \\
& & & & & \\
Agriculture Value-added, percent of & & & & & 14.63 \\
GDP & 3140 & 23.09 & 93.98 & 0.80 & 11.76 \\
Industry Value-added, percent of GDP & 3138 & 27.99 & 78.52 & 1.88 & 50.49 \\
Openness, percent of GDP & 3516 & 18.75 & 643.10 & 0.02 & 3499.39 \\
GDP per capita, 2000 USD & 3161 & 3929.94 & 20973.62 & 197.07 & 61.75 \\
Foreign Debt, percent of GDP & 3127 & 54.31 & 2079.72 & 0.11 & 354.99 \\
Inflation, in percent & 3314 & 44.68 & 12200.00 & -71.43 & 0.46 \\
Oil Exporter Dummy & 3780 & 0.31 & 1.00 & 0.00 & 1.02 \\
ICRG Corruption Score & 2066 & 2.49 & 6.00 & 0.00 & \\
\hline
\end{tabular}


Figure A1.1. Pairwise Correlations between Tax Revenue and ODA Grants
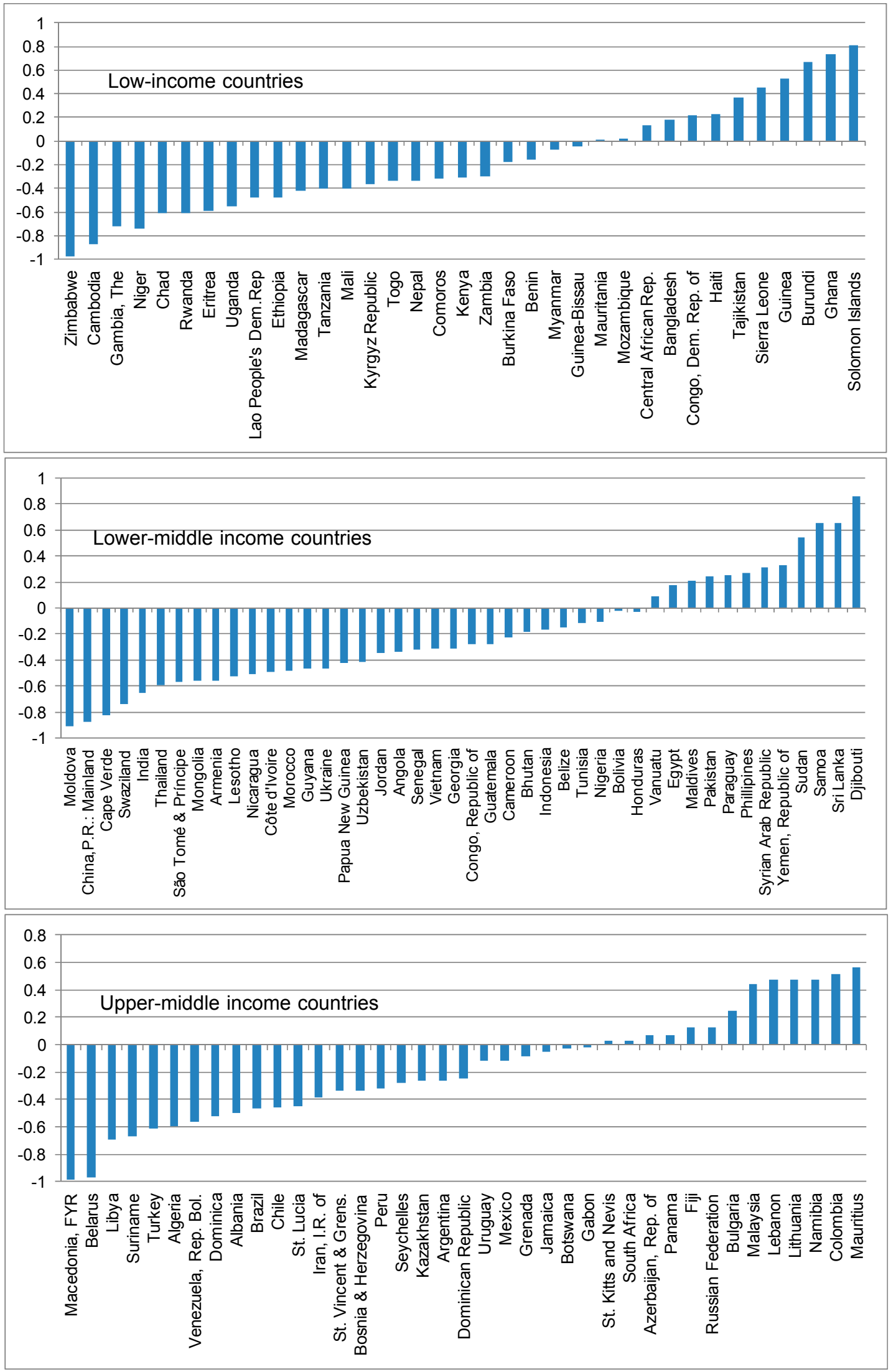


\section{Appendix II. Full Set of Controls}

Table A2.1. ODA Grants and Loans and Total Tax Revenues (Full Set of Control Variables)

\begin{tabular}{|c|c|c|c|c|}
\hline & (1) & (2) & (3) & (4) \\
\hline & $\begin{array}{c}\text { Difference } \\
\text { GMM 1/ }\end{array}$ & $\begin{array}{c}\text { System GMM } \\
2 /\end{array}$ & $\begin{array}{c}\text { Difference } \\
\text { GMM 1/ }\end{array}$ & $\begin{array}{c}\text { System GMM } \\
2 /\end{array}$ \\
\hline Tax, lagged & $\begin{array}{l}-0.3539^{*} \\
(0.2748)\end{array}$ & $\begin{array}{l}0.3599^{*} \\
(0.2223)\end{array}$ & $\begin{array}{c}0.1157 \\
(0.1536)\end{array}$ & $\begin{array}{c}0.6433^{* * *} \\
(0.0725)\end{array}$ \\
\hline Total ODA & $\begin{array}{l}-0.0332^{* *} \\
(0.0146)\end{array}$ & $\begin{array}{l}-0.0293^{*} \\
(0.0175)\end{array}$ & & \\
\hline Total ODA, squared & $\begin{array}{l}0.0002^{* *} \\
(0.0001)\end{array}$ & $\begin{array}{c}0.0002 \\
(0.0001)\end{array}$ & & \\
\hline ODA Loans & & & $\begin{array}{c}0.0021 \\
(0.0118)\end{array}$ & $\begin{array}{c}0.0076 \\
(0.0134)\end{array}$ \\
\hline ODA Loans, squared & & & $\begin{array}{l}-0.0021^{*} \\
(0.0011)\end{array}$ & $\begin{array}{l}-0.0023^{* *} \\
(0.0011)\end{array}$ \\
\hline ODA Grants & & & $\begin{array}{l}-0.0190^{* *} \\
(0.0087)\end{array}$ & $\begin{array}{l}-0.0219^{* *} \\
(0.0098)\end{array}$ \\
\hline ODA Grants, squared & & & $\begin{array}{l}0.0002^{* *} \\
(0.0001)\end{array}$ & $\begin{array}{l}0.0003^{* *} \\
(0.0001)\end{array}$ \\
\hline Inflation & $\begin{array}{c}0.0002 \\
(0.0002)\end{array}$ & $\begin{array}{c}0.0001 \\
(0.0003)\end{array}$ & $\begin{array}{c}0.0001 \\
(0.0001)\end{array}$ & $\begin{array}{c}0.0001 \\
(0.0002)\end{array}$ \\
\hline Agriculture share in Value- & & & & \\
\hline Added & $\begin{array}{c}-0.0296^{*} \\
(0.0181)\end{array}$ & $\begin{array}{c}-0.0259 \\
(0.0272)\end{array}$ & $\begin{array}{c}-0.0036 \\
(0.0091)\end{array}$ & $\begin{array}{l}-0.0115 \\
(0.0086)\end{array}$ \\
\hline Industry share in Value-Added & $\begin{array}{l}-0.0162 \\
(0.0262)\end{array}$ & $\begin{array}{l}-0.0113 \\
(0.0296)\end{array}$ & $\begin{array}{c}0.0022 \\
(0.0096)\end{array}$ & $\begin{array}{c}0.0007 \\
(0.0120)\end{array}$ \\
\hline GDP Per Capita (log) & $\begin{array}{c}0.4322 \\
(1.2780)\end{array}$ & $\begin{array}{c}0.0572 \\
(1.4431)\end{array}$ & $\begin{array}{c}0.0214 \\
(0.3363)\end{array}$ & $\begin{array}{l}-0.2305 \\
(0.1740)\end{array}$ \\
\hline Trade Openness & $\begin{array}{l}-0.0050 \\
(0.0048)\end{array}$ & $\begin{array}{l}-0.0058 \\
(0.0096)\end{array}$ & $\begin{array}{l}-0.0057^{* *} \\
(0.0024)\end{array}$ & $\begin{array}{l}-0.0065^{\star *} \\
(0.0027)\end{array}$ \\
\hline Oil Exporter & $\begin{array}{l}-0.4558 \\
(0.5238)\end{array}$ & $\begin{array}{l}-0.4458 \\
(0.5423)\end{array}$ & $\begin{array}{l}-0.0162 \\
(0.2146)\end{array}$ & $\begin{array}{l}-0.3343 \\
(0.3530)\end{array}$ \\
\hline External Debt to GDP & $\begin{array}{l}-0.0087 \\
(0.0138)\end{array}$ & $\begin{array}{l}-0.0105 \\
(0.0152)\end{array}$ & $\begin{array}{l}-0.0058 \\
(0.0096)\end{array}$ & $\begin{array}{l}0.0126 \\
0.0141\end{array}$ \\
\hline Corruption & $\begin{array}{c}0.0499 \\
(0.1597)\end{array}$ & $\begin{array}{c}0.0272 \\
(0.1640)\end{array}$ & $\begin{array}{c}0.0451 \\
(0.1421)\end{array}$ & $\begin{array}{c}0.0828 \\
(0.0659)\end{array}$ \\
\hline M1 ( $p$ value) & 0.574 & 0.573 & 0.140 & 0.025 \\
\hline M2 (p value) & 0.206 & 0.198 & 0.158 & 0.923 \\
\hline $\begin{array}{l}\text { Over-identification } \\
\quad(p \text { value })\end{array}$ & $\begin{array}{l}\text { Hansen: } \\
0.756\end{array}$ & $\begin{array}{l}\text { Hansen: } \\
0.700\end{array}$ & $\begin{array}{l}\text { Hansen: } \\
0.702\end{array}$ & $\begin{array}{c}\text { Hansen: } \\
0.297\end{array}$ \\
\hline Observations & 1395 & 1455 & 1395 & 1455 \\
\hline Number of instruments & 46 & 48 & 69 & 72 \\
\hline Number of countries & 76 & 76 & 76 & 76 \\
\hline
\end{tabular}

Note: Dependent variable is total tax revenue to GDP. Full set of year dummies in all regressions.

Robust standard errors, in parenthesis; ${ }^{* * *}\left({ }^{* *},{ }^{*}\right)$ indicate significance at $1(5,10)$ percent.

$1 /$ Two step, robust, instruments based on second lags of tax and ODA.

2/ Two step, robust, with instruments based on first lag of differences in tax and ODA in levels equation, and second lags of their levels in the differenced equation. 


\section{Appendix III. Revenue Impact of ODA Grants}

Table A3.1. Estimated Revenue Offset from an Additional Dollar of ODA Grants

\begin{tabular}{lcccc}
\hline & $\begin{array}{c}\text { Sample Average } \\
\text { (Percent of GDP) }\end{array}$ & \multicolumn{2}{c}{ Estimated Coefficient 1/ } & Impact \\
\cline { 3 - 4 } & 16.08 & -0.0151 & 0.0002 & -23.96 \\
\hline Total Tax Revenue & 4.30 & -0.1139 & 0.0045 & -47.04 \\
VAT & 4.01 & 0 & 0.0002 & 0.08 \\
Trade Taxes & 1.90 & -0.0788 & 0.0035 & -14.31 \\
Excises & 4.68 & 0 & -0.0003 & -0.14 \\
\hline
\end{tabular}

1/ From Tables 1-2, based on system-GMM estimates. For non-statistically significant, a coefficient of zero is assumed. 


\section{REFERENCES}

Baltagi, B., 2008, “Econometric Analysis of Panel Data," Wiley, 4 ${ }^{\text {th }}$ Edition, 2008.

Baungaard, T., and M. Keen, 2010, “Tax Revenue and (or?) Trade Liberalization,” Journal of Public Economics, Elsevier, Vol. 94(9-10), pp. 563-77, October.

Blundell, R., and S. Bond, 1998, "Initial Conditions and Moment Restrictions in Dynamic Panel Data Models," Journal of Econometrics, 87, pp. 115-43.

Bornhost, F., S. Gupta, and J. Thornton, 2009, "Natural Resource Endowments and the Domestic Revenue Effort," European Journal of Political Economy, Elsevier, Vol. 25(4), pp. 439-46, December.

Brautigam, D., and S. Knack, 2004, "Foreign Aid, Institutions, and Governance in SubSaharan Africa," Economic Development and Cultural Change, Vol. 52(2), pp. 25585 , January.

Brun, J. F., G. Chambas, and B. Laporte, 2011, “Tax Performance in Developing Countries: Do IMF Programs Work?” Draft paper.

Carter, P., 2011, Foreign Aid and Taxation, revisited, mimeo.

Chow, C., 1960, “Tests of Equality Between Sets of Coefficients in Two Linear Regressions," Econometrica, 28, pp. 591-605.

Clist, P., and O. Morrissey, 2011, "Aid and Tax Revenue: Signs of a Positive Effect since the 1980s," Journal of International Development, 23, pp. 165-80.

Collier, P., 2006, "Is Aid Oil? An Analysis of Whether Africa Can Absorb More Aid," World Development, 34(9), pp. 1482-97.

Collier, P., and A. Venables, 2008, "Illusory Revenues: Import Tariffs in Resource-rich and Aid-rich Economies," Journal of Development Economics, Vol. 94, pp. 202-06.

Djankov, S., Montalvo. J., and M. Reynal-Querol, 2008, “The Curse of Aid,” Journal of Economic Growth, 13, pp. 169-94.

Fagernäs, S., and J. Roberts, 2004, “The Fiscal Effects of Aid in Zambia," ESAU Working Paper 10, Overseas Development Institute, London, U.K. 
, 2004, "The Fiscal Effects of Aid in Uganda," ESAU Working Paper 9, Overseas Development Institute, London, U.K.

Fagernäs, S., J. Roberts, and C. Schurich, 2004, "The Fiscal Effects of Aid in Malawi," ESAU Working Paper 7, Overseas Development Institute, London, U.K.

Franco-Rodriguez, S., M. McGillivray, and O. Morrissey, 1998, "Aid and the Public Sector in Pakistan: Evidence with Endogenous Aid," World Development, 26:7, pp. 1241-50.

Gambaro, L., J. Meyer-Spasche, and R. Ashikur, 2007, "Does Aid Decrease Tax Revenue in Developing Countries?” London School of Economics, March.

Ghura, D., 1998, "Tax Revenue in Sub-Saharan Africa: Effects of Economic Policies and Corruption,” IMF Working Paper 98/135 (Washington: International Monetary Fund).

Gibson, C., K. Andersson, E. Ostrom, and S. Shivakumar, 2005, The Samaritan's Dilemma The Political Economy of Development Aid, Oxford University Press.

Gupta, S., B. Clements, A. Pivovarsky, and E. R. Tiongson, 2004, "Foreign Aid and Revenue Response: Does the Composition of Aid Matter?" Chapter 14 in S. Gupta, B. Clements, and G. Inchauste (ed.), Helping Countries Develop: The Role of Fiscal Policy (Washington: International Monetary Fund).

Gupta, S., B. Clements, and S. Tareq, 2008, "Mobilizing Revenue," Finance and Development, Vol. 45, Issue 3 (Washington: International Monetary Fund).

Heller, P., 1975, "A Model of Public Fiscal Behaviour in Developing Countries: Aid, Investment and Taxation," American Economic Review, Vol. 65 (June), pp 429-45.

Heller, P., and S. Gupta, 2002, "More Aid—Making it Work for the Poor," World Economics, Vol. 3, No. 4.

International Monetary Fund, 2011, "Revenue Mobilization in Developing Countries," Available at: www.imf.org/external/np/pp/eng/2011/030811.pdf

Keen, M., and M. Mansour, 2010, "Revenue Mobilisation in Sub-Saharan Africa: Challenges from Globalisation I - Trade Reform," Development Policy Review, Overseas Development Institute, Vol. 28(5), pp. 553-71, 09.

Keen, M., and M. Mansour, 2010, "Revenue Mobilisation in Sub-Saharan Africa: Challenges from Globalisation II - Corporate Taxation," Development Policy Review, Overseas Development Institute, Vol. 28(5), pp. 573-96, 09. 
Knack, S., 2000, “Aid Dependence and the Quality of Governance: A Cross-country Empirical Analysis," Policy Research Working Paper Series 2396 (Washington: The World Bank).

, 2009, "Sovereign Rents and the Quality of Tax Policy and Administration," Journal of Comparative Economics, Elsevier, Vol. 37(3), pp. 359-71, September.

Moss, T., G. Pettersson, and N. van de Walle, 2008, “An Aid-institutions Paradox? A Review Essay on Aid Dependency and State Building in Sub-Saharan Africa," In W. Easterly (Ed), Reinventing Foreign Aid, Cambridge, MA: The MIT Press.

Nickell, S., 1981, "Bias in Dynamic Models with Fixed Effects,” Econometrica, 49(6), pp. 1417-26.

Osei, R., O. Morrissey, and T. Lloyd, 2005, “The Fiscal Effects of Aid in Ghana,” Journal of International Development, 17(8), pp. 1037-54.

Pack, H., and J. R. Pack, (1990) "Is Foreign Aid Fungible? The Case of Indonesia," Economic Journal, 100, pp. 188-94.

Remmer, K., 2004, “Does Foreign Aid Promote the Expansion of Government?” American Journal of Political Science, 48(1), 77-92.

Roodman, D., 2009, “A Note on the Theme of Too Many Instruments," Oxford Bulletin of Economics and Statistics 71(1), pp.135-58.

Rodrik, D., 1998, “Why Do More Open Economies have Bigger Governments?” Journal of Political Economy, Vol. 106, pp. 997-1032.

Roy, S., 1957, "Some Aspects of Multivariate Analysis,” Wiley.

Sen Gupta, A., 2007, “Determinants of Tax Revenue Efforts in Developing Countries,” IMF Working Paper 07/184 (Washington: International Monetary Fund).

Smith, R., 2001, "Estimation and Inference with Non-stationary Panel Time-series Data," Paper prepared for the RC33 Conference, Cologne October 2000, Department of Economics, Birkbeck College, London. 
United Nations Development Program, 2010, "What Will It Take To Achieve the Millennium Development Goals? An International Assessment,” June.

http://www.undp.org/content/undp/en/home/librarypage/mdg/international-assessment--english-full-version.html

United Nations Millennium Report, 2005, "Investing in Development, A Practical Plan to Achieve the Millennium Development Goals." http://www.unmillenniumproject.org/reports/fullreport.htm

Villela, L. A., A. Lemgruber, and M. Jorratt, 2010, "Tax Expenditure Budgets: Concepts and Challenges for Implementation,” IDB Working Paper Series No. IDB-WP-131, April. (Washington: Inter-American Development Bank).

Zellner, A., “An Efficient Method of Estimating Seemingly Unrelated Regression and Tests for Aggregation Bias," Journal of the American Statistical Association, Vol. 57. 